\title{
A New First Year Design Course at the University of Western Ontario
}

\author{
Ralph Buchal, Director of Integrated Engineering and Design Education \\ Edwin Gibb, Faculty of Education \\ F. Michael Bartlett, Department of Civil and Environmental Engineering \\ Sean Hinchberger, Department of Civil and Environmental Engineering \\ Shahzad Barghi, Department of Chemical and Biochemical Engineering \\ Amarjeet Bassi, Department of Chemical and Biochemical Engineering \\ Kenneth McIsaac, Department of Electrical and Computer Engineering \\ Jayshri Sabarinathan, Department of Electrical and Computer Engineering \\ Abbas Samani, Department of Electrical and Computer Engineering \\ Xeuliang (Andy) Sun, Department of Mechanical and Materials Engineering \\ The University of Western Ontario \\ London, Ontario \\ rbuchal@eng.uwo.ca
}

\begin{abstract}
A new first year design course at the University of Western Ontario uses team design projects to develop skills in the engineering design process, teamwork, design communication, and reflection. Students begin with a short 6-week mini-project, which is followed by an 18-week major design project. Each student is required to prepare an individual "State-of-the-art" report at the beginning of the major project. Students work through the stages of the design process, starting with conceptual design to generate innovative concepts. This is followed by design validation using analysis, simulation and experiments, CAD modeling, and prototype construction and testing.
\end{abstract}

\section{Introduction and background}

After years of neglect, design experience, practical knowledge and soft skills have again become important objectives of engineering education. These skills are demanded by industry $[1,2]$, and have been incorporated into ABET [3] and CEAB [4] accreditation criteria. Recently, the Canadian Design Engineering Network (CDEN) was formed "to promote the development and sharing of educational engineering tools among all Engineering Schools within Canadian Universities [5]." The need has also been recognized by the Natural Sciences and
Engineering Research Council of Canada (NSERC), which has established the Chairs in Design Engineering Program to "improve the level and quality of design engineering activity within Canadian universities [6]."

In response, the University of Western Ontario introduced a new first year design course, ES 050, in $2003 / 2004$ [7]. ES 050 is a project-driven course emphasizing innovation and creativity. It is a full year double-credit course taken by all first year Western engineering students.

ES 050 is unlike other engineering courses in that it deals with open-ended problems with multiple possible solutions. For most students, this is their first experience with open-ended problems.

\section{Course goals}

The course is designed to provide students with the following opportunities:

1. To practice engineering design. Experience with the large-scale design objects in ES 050 will provide the context for:

a. Learning the engineering design process; 
b. Identifying and experiencing the application of fundamental engineering principles and problem-solving methods to engineering design;

c. Recognizing the potential of effective teamwork in the problem-solving process;

d. Developing oral, written and graphical communication skills to effectively document and communicate engineering designs.

2. To develop independent-learning skills necessary for success as a student and as a Professional Engineer.

3. To encounter and appreciate different engineering disciplines.

4. To develop and demonstrate ethical and professional conduct required from a Professional Engineer.

\section{Specific learning objectives}

The specific learning objectives are listed below.

1. To learn through experience the engineering design process, including:

- Statement of need/ problem definition

- Information gathering and research

- Concept generation and innovation

- Identification of design objectives and constraints

- Justification of eventual design choice

- Design iteration

- Interdisciplinary perspective and approach
- Application of engineering science in design evaluation

- Project budgeting

- Effective prototype development

- Use of CAD and engineering graphics

2. To develop teamwork and individual skills, including:

- Individual responsibility and accountability

- Dispute-resolution

- Team meetings

- Team communications

- Project management, including setting goals, prioritizing tasks, and meeting deadlines

3. To communicate technical information in oral, written or graphic forms, including:

- Preparation

- Documented research

- Content: what is presented

- Mechanics: how it is presented

- Delivery

4. To reflect on one's achievements, recognizing ways to improve, including:

- Learning from failures

- Personal growth towards becoming a Professional Engineer

\section{Deliverables and learning objectives}

ES 050 has a number of individual and team deliverables, each addressing specific learning objectives as shown in Table 1. 
Table 1. Deliverables and Learning Objectives.

\begin{tabular}{|c|c|c|c|c|c|c|}
\hline \multirow[t]{2}{*}{ Deliverable } & \multicolumn{2}{|c|}{ Marks } & \multicolumn{4}{|c|}{ Learning Objectives } \\
\hline & 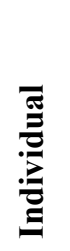 & $\stackrel{\Xi}{\Xi}$ & 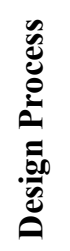 & 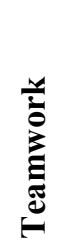 & 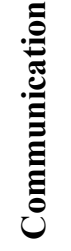 & 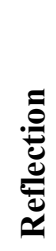 \\
\hline \multicolumn{7}{|c|}{ Creativity Vignette } \\
\hline Concept list & & 2.5 & $\mathrm{X}$ & $\mathrm{X}$ & & \\
\hline Design Sketches & 2.5 & & & & $\mathrm{X}$ & \\
\hline Prototype and Presentation & & 2.5 & & $\mathrm{X}$ & $\mathrm{X}$ & \\
\hline Design Report & & 5 & $\mathrm{X}$ & $\mathrm{X}$ & $\mathrm{X}$ & $\mathrm{X}$ \\
\hline Design Notebook & 2.5 & & $\mathrm{X}$ & & $\mathrm{X}$ & $\mathrm{X}$ \\
\hline \multicolumn{7}{|c|}{ Major Design Project } \\
\hline SOTA Report & 10 & & $\mathrm{X}$ & & $\mathrm{X}$ & \\
\hline Lead Engineer Presentation & 7.5 & & & $\mathrm{X}$ & $\mathrm{X}$ & \\
\hline Phase Reports & & 60 & $\bar{X}$ & $\mathrm{X}$ & $\mathrm{X}$ & $\mathrm{X}$ \\
\hline Experiment Proposal & & 5 & $\mathrm{X}$ & $\mathrm{X}$ & $\mathrm{X}$ & \\
\hline CAD test & 10 & & $\bar{X}$ & & $\mathrm{X}$ & \\
\hline Project Prototype & & 5 & $\mathrm{X}$ & $\mathrm{X}$ & $\mathrm{X}$ & \\
\hline Design Notebook & 7.5 & & $\mathrm{X}$ & & $\mathrm{X}$ & $\mathrm{X}$ \\
\hline Final Examination & 10 & & & & $\mathrm{X}$ & $\mathrm{X}$ \\
\hline Totals & 50 & 50 & & & & \\
\hline
\end{tabular}

4.1 Learning the design process through projects Students begin with a short 6-week mini-project called a Creativity Vignette. This is followed by an 18 -week Major Design Project. Each student is required to prepare an individual "State-of-the-art" report at the beginning of the major project. Students work through the stages of the design process, starting with conceptual design to generate innovative concepts. This is followed by design validation using analysis, simulation and experiments, CAD modeling, and prototype construction and testing.

The Creativity Vignette and Major Design Project change every year, and are designed to be open-ended to encourage creativity and innovation.

\subsection{Creativity vignette}

The Creativity Vignette is a "snapshot" of the Engineering Design Process. The objectives of the Creativity Vignette are to practice and obtain feedback on the various steps of the engineering design process; and to learn to utilize creativity and innovation in engineering design. This experience provides practice and insights that will be useful in the Major Design Project.
In 2004-05, students were asked to "Design Something Innovative that Helps", with materials and parts that have a commercial value less than $\$ 15$. Figure 1 shows one of the more successful solutions - a "Better Snow Shovel".

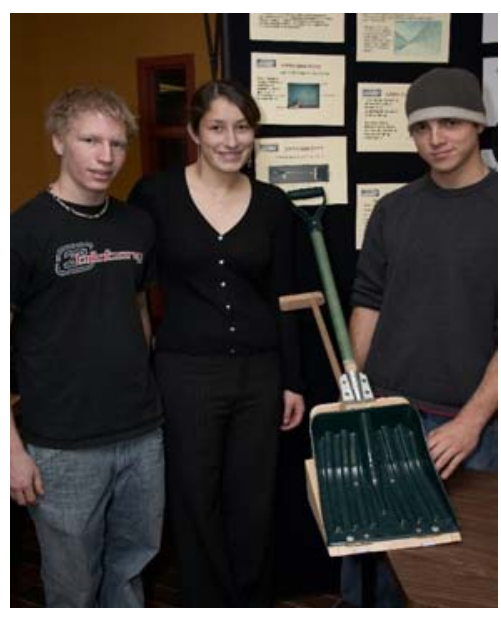

Figure 1. Students displaying a creativity vignette prototype of a "better show shovel" 


\subsection{Major design project}

Student design teams were required to design an interactive exhibit that demonstrates an important scientific principle or engineering technology to the general public. The exhibit should be suitable for incorporation as part of a science center, an outdoor science fair, or as an activity or demonstration at an engineering day camp. The design must be rugged enough to survive its expected life cycle of interaction with its target audience and with its environment.

The interactive science or engineering exhibit design could lead to an apparatus used for these two purposes: stimulating teaching for students and amusement/learning for children. Accordingly, the designs should consider safety and legal issues, possible support from governmental organizations and industrial entities, and marketing opportunities.

The Major Design Project culminates in a Design Showcase, held during the last week of classes. This event is held in a large banquet hall, where all student teams exhibit and describe to judges their design prototypes. Figure 2 shows a cluster of students being judged. Guests from the campus and community are invited to this exciting event, and feedback has been very positive.

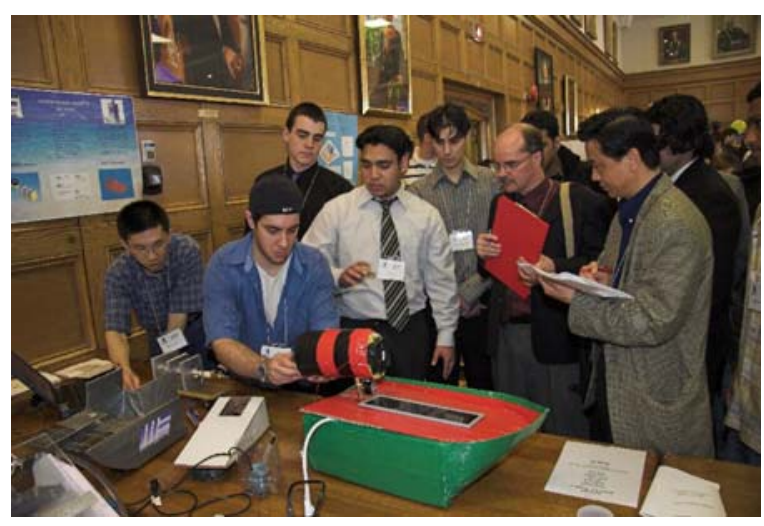

\section{Figure 2. Adjudication of a major design prototype at the Design Showcase}

\subsection{Teamwork}

Students develop teamwork skills by working in teams of three, and clusters of nine. Team membership within each cluster is rotated during each of three phases. Team leadership is also rotated. Team leaders are responsible for preparing regular progress memos and design presentations. Each team prepares a design report at the end of each phase.

\subsection{Written, oral and graphical communication} Students develop design communication skills by giving oral presentations, and by preparing design reports including engineering sketches and drawings to document their designs.

\subsection{Reflection}

Students are required to reflect on lessons learned, and to suggest improvements, at each stage. Design is an iterative process, and engineers develop judgment by learning from experience and failures.

\section{Course delivery}

The course is team taught, with instructors from every department. The timetable consists of one weekly lecture to the entire class, four weekly interactive workshops of about 90 students each, and multiple weekly studios of about 45 students each. Different instructors are assigned to each studio, and interact very closely with the students.

\subsection{Main lecture}

A one-hour weekly lecture to the entire class is used to introduce important topics. These topics include: the design process, health and safety, teamwork, oral and written communication, engineering graphics, CAD, Professionalism and ethics, and an introduction to design in the different engineering disciplines.

In particular, several weeks are devoted to introducing basic engineering science from various disciplines. The purpose is to expose students to the different disciplines, and to provide engineering background required for their major projects.

\subsection{Workshop}

The lecture topics are expanded in weekly two-hour interactive workshops.

\subsection{Studios}

The most important element is the weekly studio, which is devoted to guided work on design projects. The studios involve close interaction between the instructors and students. The role of the instructors is to guide, advise and provide feedback, not to lecture.

\section{$5.4 \quad$ Team meetings}

In addition to contact time with instructors, ES 050 timetables contain a weekly 2-hour slot for student team meetings. Much of the work on the design projects is done outside regular class times, and this ensures that students have a conflict-free time for weekly meetings. Students often also meet with their 
studio instructors, either in teams or as individuals, in team meeting time.

\subsection{Course Co-ordination}

To co-ordinate the course activities, weekly hour-long instructors meetings were held. Individuals responsible for preparing major instructional materials were identified, techniques for motivating students to improve their performance were reviewed, and specific problem cases were discussed to expedite fair and consistent responses. Each studio instructor submitted outstanding, average and poor submissions received for each major assignment to the Course Ombusdperson, who reviewed them for consistency. Typically the grading was quite consistent, likely because each instructor tended to grade consistently around the average in each studio, which were reasonably uniform between studios.

\section{CAD and engineering graphics}

CAD and engineering graphics are important topics in design that were previously taught in a separate course. The approach in ES 050 is to introduce students to the basics of engineering drawing and CAD, which they apply in their projects.

The importance of instrument drawing and drafting have declined in recent years with the advent of CAD tools, but the basic skills are still important. ES 050 follows the general trend toward emphasis on sketching and freehand drawing, using proper engineering drawing standards. Sketching is used to teach standard graphics topics including:

- Multiview drawing

- $\quad$ Pictorial drawing (e.g. Isometric)

- $\quad$ Section views

- Auxiliary views

- Dimensioning and tolerancing

- Working drawings

These skills are used to document design ideas as engineering sketches in design notebooks.
Subsequently, these design ideas are modeled using 3D CAD software. The software used in ES 050 is SolidWorks, but the generic skills and concepts are transferable to any CAD software.

The generic concepts are introduced through lectures and interactive demonstrations. Students are then selftaught on the particulars by completing on-line CAD tutorials. Typically only a few hours are needed to develop skills in the following key areas:

- Creation of solid models of parts

- Creation of assembly models consisting of multiple parts

- Generation of detail and assembly drawings from CAD models.

Many students have developed impressive CAD skills, including use of design analysis tools like COSMOS Works and COSMOS Motion.

\section{Assessment and evaluation}

\subsection{Formative assessment rubric}

A formative assessment rubric is used to explicitly define expected levels of achievement for each of the learning objectives. The rubric provides clear expectations, and is used for feedback.

Unlike a traditional mark breakdown, the rubric provides a brief description of different levels of achievement for each criterion. The rubric criteria correspond directly to the course learning objectives.

The ES 050 formative assessment rubric contains a total of 26 criteria, in four broad categories: the design process, teamwork, communication and reflection. Table 2 shows sample rubric criteria for assessing the lead engineer presentation. 
Table 2. Sample assessment rubric for lead engineer presentation

\begin{tabular}{|c|c|c|c|}
\hline Criterion & $\begin{array}{l}\text { Does Not Meet } \\
\text { Expectations }\end{array}$ & Meets Expectations & Exceeds Expectations \\
\hline Preparation & $\begin{array}{l}\text { Insufficient preparation to } \\
\text { present confidently. Well } \\
\text { over or under time allotted. } \\
\text { Graphics confuse or of poor } \\
\text { quality. Unprepared to } \\
\text { implement available } \\
\text { technology. }\end{array}$ & $\begin{array}{l}\text { Sufficient preparation to } \\
\text { present confidently. Slightly } \\
\text { over or under time allotted. } \\
\text { Graphics legible, clean and } \\
\text { relevant. Sufficiently } \\
\text { prepared to implement } \\
\text { available technology. }\end{array}$ & $\begin{array}{l}\text { Confidence exuded, even } \\
\text { during unexpected mishap. } \\
\text { On time or very close. } \\
\text { Innovative graphics reinforce } \\
\text { topic. Creatively } \\
\text { implements available } \\
\text { technology, beyond basics } \\
\text { taught in class. }\end{array}$ \\
\hline $\begin{array}{l}\text { Mechanics: how } \\
\text { it is presented }\end{array}$ & $\begin{array}{l}\text { No logical sequence to } \\
\text { information. Poor } \\
\text { formatting and layout. No } \\
\text { greeting, introduction, } \\
\text { outline, or summary. Poor } \\
\text { word choice and many } \\
\text { grammatical errors. Many } \\
\text { spelling mistakes. }\end{array}$ & $\begin{array}{l}\text { Clear sequence to } \\
\text { information presented. Good } \\
\text { formatting and layout. } \\
\text { Includes greeting, } \\
\text { introduction, outline and } \\
\text { summary. Good word } \\
\text { choice, few grammar errors, } \\
\text { few spelling mistakes. }\end{array}$ & $\begin{array}{l}\text { Creatively articulates ideas } \\
\text { in a clear and concise } \\
\text { manner. All necessary } \\
\text { components are included and } \\
\text { satisfying. Excellent word } \\
\text { choice, no grammar or } \\
\text { spelling mistakes. } \\
\text { Professional layout. }\end{array}$ \\
\hline $\begin{array}{l}\text { Oral } \\
\text { presentation: } \\
\text { Delivery }\end{array}$ & $\begin{array}{l}\text { No enthusiasm. Hard to } \\
\text { follow. Poor eye contact or } \\
\text { body language. Hard to } \\
\text { hear. Reads from notes or } \\
\text { slides. Misunderstands } \\
\text { questions and provides } \\
\text { incoherent answers without } \\
\text { seeking clarification. }\end{array}$ & $\begin{array}{l}\text { Moderate enthusiasm. } \\
\text { Acceptable but flat delivery. } \\
\text { Good eye contact and body } \\
\text { language. Provides coherent } \\
\text { answers to questions as } \\
\text { posed. }\end{array}$ & $\begin{array}{l}\text { Unmistakable enthusiasm for } \\
\text { topic. Powerful, dynamic, } \\
\text { fluid delivery. Answers add } \\
\text { value to questions posed. }\end{array}$ \\
\hline $\begin{array}{l}\text { Content: what is } \\
\text { presented }\end{array}$ & $\begin{array}{l}\text { Does not appear to have a } \\
\text { grasp of the topic. Material } \\
\text { presented is superficial or } \\
\text { incorrect. }\end{array}$ & $\begin{array}{l}\text { Appears to have sound } \\
\text { knowledge base of topic. } \\
\text { Material presented is } \\
\text { accurate and relevant. }\end{array}$ & $\begin{array}{l}\text { Insightful understanding of } \\
\text { topic. Material is meaty, } \\
\text { sufficient, accurate and } \\
\text { relevant. }\end{array}$ \\
\hline $\begin{array}{l}\text { Overall } \\
\text { Effectiveness }\end{array}$ & $\begin{array}{l}\text { Material and delivery } \\
\text { unsuitable for audience. Not } \\
\text { persuasive. }\end{array}$ & $\begin{array}{l}\text { Material and delivery } \\
\text { suitable for audience. } \\
\text { Moderately persuasive. }\end{array}$ & $\begin{array}{l}\text { Material and delivery } \\
\text { tailored to audience. Very } \\
\text { persuasive. }\end{array}$ \\
\hline
\end{tabular}

\subsection{Evaluation}

The grading scheme for each deliverable is based on the rubric criteria being evaluated. Table 3 shows the lead engineer presentation evaluation criteria, based on the assessment rubric shown in Table 2.

\section{Table 3. Evaluation criteria for lead engineer} presentation.

\begin{tabular}{|c|c|}
\hline Criterion & Points \\
\hline Preparation and Mechanics & 6 \\
\hline Oral presentation: Delivery & 3 \\
\hline Content & 4 \\
\hline Overall Effectiveness & 2 \\
\hline Total Points & 15 \\
\hline
\end{tabular}

\section{Design phases and bucket grading}

The Major Design Project is divided into three 6-week phases, with a report and presentation at the end of each phase. The phases correspond to the stages of the design process as follows:

1. Phase 1: Conceptual Design
a. Project planning
b. Problem definition
c. Generation and evaluation of alternatives
d. Sketches and freehand engineering drawings 
2. Phase 2: Engineering Analysis and Validation

b. Experiments and testing to validate concepts

3. Phase 3: Final Design and Implementation
a. CAD modeling and design documentation
b. Prototype construction
c. Reflection and iteration

A "bucket grading" system [8] is used to evaluate the Major Design Project Phase Reports.

The first two Phase Reports allow the student to accumulate points in specified categories, or buckets, while at the same time providing the student with feedback to prompt further improvements. In the Phase One and Phase Two reports, points can be earned in the categories of Innovations, Validation of Innovations by Engineering Science, and Communication. In the Phase Three report, marks can be earned in each of these categories and can also be earned for Overall Design.

The categories of Innovations, Validation of Innovations by Engineering Science, and Communication are generically termed "Buckets" because points earned in these categories can accumulate with each successive Phase Report. To pass the course, each student is required to have a minimum of 8 points in each of these three buckets, and is also required to have a minimum of 8 points for Overall Design. There are no upper limits on the number of points that a student can earn in any bucket, but the maximum number of marks that any student can receive for the three Phase Reports is 60.

This form of evaluation has been adopted for the ES 050 Major Design Project because it allows students to improve their design based on feedback from the Studio Instructor and earn additional marks for the improvement in a subsequent Phase Report. It also allows students that achieve the minimums in each bucket to earn marks in categories that they may be proficient in: one student may earn half of his or her marks in the Innovation category while another could earn half of his or her marks in Validation by Engineering Science. And it rewards students who effectively plan and manage their time to earn most of their marks by the end of Phase Two - they need only earn marks in Phase Three for the Overall Design, and so presumably have time to devote to their other first year courses.

The accumulation of points in the different buckets is illustrated in Figure 3.

\subsection{Innovation Bucket}

Each team of three will receive:

- 6 points for each Outstanding Innovation

- 3 points for each Good Innovation

- 1 point for each Modest Innovation

- 0 points for solutions that are simply based on existing solutions.

Outstanding innovations from the 2003/04 ES 050 Course included:

- a system of telescoping tubes that allowed the structure of a shelter to be compressed into a very small volume for transport;

- a balanced current inverter that advanced the state-of-the-art of transforming DC power to AC power;

- $\quad$ light-emitting polymers to illuminate living space using little power

\subsection{Validation of Innovation by Engineering Science Bucket}

Each team of three will receive:

- 6 points for each Innovation that has been sufficiently validated to be accepted or rejected with confidence, using appropriate engineering science.

- 3 points for each Innovation that has been sufficiently validated to be accepted or rejected with a level of uncertainty or risk, using appropriate engineering science.

- 1 point for using appropriate engineering calculations to validate modifications to a conventional concept.

- 0 points for validations that are not convincing. 
Examples of outstanding innovations from the 2003-04 ES 050 projects include:

- Balanced current inverter validated using MultiSim simulation

- Prefabricated stud wall assembly validated using CAD and full-scale prototyping

- Multi-component water filter validated using conventional engineering science and prototyping

\subsection{Communication Bucket}

Each team, whether it comprises two, three, or four members, will receive:

- 4 points for a concise, effective, error-free report with effective figures and tables.

- 2 points for a report that resembles a complete first draft because it has not been effectively proof read and edited.

- 0 points for a report that is incomplete, or full of grammar and spelling errors, or incomprehensible.

\subsection{Overall Design Bucket}

The overall design as presented in the Phase Three report will be evaluated holistically based on

- the effectiveness of CAD drawings and other material used to describe the final design

- the harmony of the design: how well its components are integrated

- the significance of the design to a customer, a company, the engineering profession and/or society at large.

Each team of three will receive:

- $\quad 16$ points for an overall design that exceeds all expectations

- 12 points for an overall design that meets all expectations

- 8 points for an overall design that meets minimum expectations.

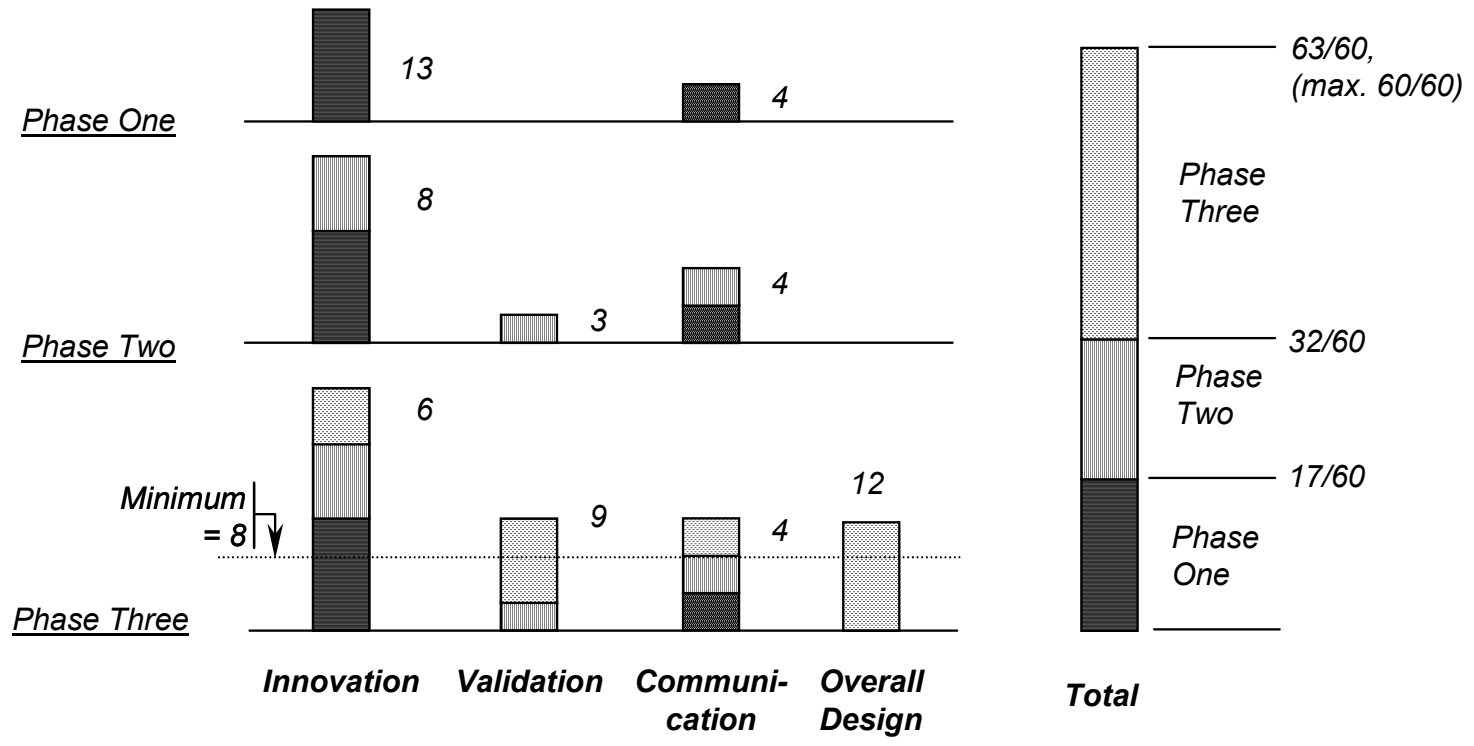

Figure 3. Example of bucket grading

\subsection{Team grade distribution}

A team grade distribution form is used to allocate team grades to individual team members. The team and studio instructor must agree in writing to the percentage of team grade allocated to each member. In most cases, the allocation is equal. 


\section{Final examination}

All students write a closed-book final exam during the regular exam period. The purpose of the exam is to evaluate the lessons learned about engineering design. The exam questions are known ahead of time, and students are expected to reflect and prepare answers to the following questions:

\subsection{Question 1 - Innovation and Creativity (25\%):}

Identify and describe innovative outcomes from the Major Design Project and the Creativity Vignette. Describe the problem-definition and creativity generating tools used both individually and with your teammates to achieve these outcomes.

\subsection{Question 2 - Decision-Making (15\%):}

Describe decision-making processes used both when making design choices and when assigning work to team members in the Major Design Project. Comment on your performance as a leader during the phase when you were Lead Engineer.

\subsection{Question 3 - Communication (10\%):}

Identify improvements in your ability to communicate engineering design with mathematical, oral, written and graphical communication tools during ES 050 .

\subsection{Question 4 - Project Management (15\%):} Identify and describe the use of any project management tools used to complete the Major Design Project. Discuss their attributes and deficiencies.
Comment on your performance as a facilitator during the phase when you were Lead Engineer.

\subsection{Question 5 - Engineering Science (20\%):}

Identify any principles, laws, or theories that were incorporated in your design solutions for the Major Project.

\subsection{Question 6 - Reflection (15\%):}

What lessons have you learned in ES 050 to improve your design solutions, personal performance or team performance in the Major Design Project.

\section{Observations and conclusions}

During its first two years, ES 050 has taken enormous effort to teach. The logistics of coordinating multiple instructors and many TAs were formidable, and the instructor workload was significantly greater than for other courses of equivalent weight. However, many aspects of the course structure and management have been improved over the last year, and many further improvements are planned.

The challenge is to reduce the effort and resources required without negatively affecting the tremendous educational value of the course.

Many of the most innovative and valuable features of ES 050 were also the most difficult and problematic. To improve the course, a cost/benefit analysis of each element is required. The elements are listed and assessed in Table 4.

Table 4. Assessment of key course elements

\begin{tabular}{|c|c|c|}
\hline Element & Pros & Cons \\
\hline $\begin{array}{l}\text { Open-ended } \\
\text { design projects }\end{array}$ & $\begin{array}{ll}\text { - } & \text { Realistic engineering experience } \\
\text { - Highly motivating }\end{array}$ & $\begin{array}{ll}\text { - } & \text { Students have little previous experience } \\
& \text { with open-ended problems } \\
\text { - } & \text { Confusion about expectations } \\
\text { - Students lack engineering knowledge } \\
\text { - Some students rely heavily on } \\
\text { instructors for guidance }\end{array}$ \\
\hline $\begin{array}{l}\text { Prototype } \\
\text { construction }\end{array}$ & $\begin{array}{l}\text { - Essential element of the "design-build- } \\
\text { test" approach to design education } \\
\text { - Links theory and practice }\end{array}$ & $\begin{array}{ll}- & \text { Limited workshop space and resources } \\
- & \text { Students lack skills } \\
- & \text { Safety concerns }\end{array}$ \\
\hline Bucket Grading & $\begin{array}{ll}\text { - } & \text { Flexible assessment in different } \\
& \text { categories } \\
\text { - } & \text { Does not penalize early failures } \\
\text { - } & \text { Provides feedback } \\
\end{array}$ & $\begin{array}{ll}\text { - } & \text { Novelty creates initial confusion } \\
\text { - } & \text { Very time consuming for instructors }\end{array}$ \\
\hline $\begin{array}{l}\text { Interactive studio } \\
\text { approach }\end{array}$ & $\begin{array}{ll} & \text { Very effective learning environment } \\
\text { - } & \text { Extensive, timely guidance feedback and }\end{array}$ & $\begin{array}{l}\text { - Heavy instructor workload } \\
\text { - Individual and small group } \\
\text { "apprenticeship" is inefficient for a large } \\
\text { class }\end{array}$ \\
\hline
\end{tabular}




\begin{tabular}{|c|c|c|}
\hline Element & Pros & Cons \\
\hline $\begin{array}{l}\text { Weekly } \\
\text { Interactive } \\
\text { Workshops }\end{array}$ & - $\quad$ Effective if sufficiently interactive & $\begin{array}{ll}\text { - } & \text { Interactivity is difficult to incorporate } \\
\text { - } & \text { Lecture rooms not suited to interactive } \\
\text { activities } \\
\text { - } & \text { Low attendance if not seen as relevant }\end{array}$ \\
\hline Main Lecture & $\begin{array}{ll}\text { - } & \begin{array}{l}\text { Efficient means of delivering } \\
\text { information }\end{array}\end{array}$ & - Low attendance if not seen as relevant \\
\hline $\begin{array}{l}\text { Introduction of } \\
\text { engineering } \\
\text { science } \\
\text { fundamentals }\end{array}$ & $\begin{array}{l}\text { - Introduces the disciplines, and the } \\
\text { importance of engineering science in } \\
\text { design } \\
\text { - Some engineering science is required for } \\
\text { the major design projects }\end{array}$ & $\begin{array}{l}\text { - The main purpose is not to teach } \\
\text { engineering science } \\
\text { - Difficult to provide enough for a } \\
\text { diversity of projects. }\end{array}$ \\
\hline $\begin{array}{l}\text { Emphasis on } \\
\text { reports for } \\
\text { evaluation }\end{array}$ & $\begin{array}{l}\text { Opportunity for rich and extensive } \\
\text { feedback } \\
\text { - Appropriate for evaluating design } \\
\text { projects }\end{array}$ & $\begin{array}{l}\text { - } \quad \text { Very heavy marking load for instructors } \\
\text { - } \quad \text { TAs are not qualified to mark reports } \\
\text { - } \quad \text { Some students don't read feedback }\end{array}$ \\
\hline $\begin{array}{l}\text { Large team size, } \\
\text { rotating } \\
\text { membership }\end{array}$ & $\begin{array}{ll}\text { - } & \text { Opportunity for all to be leader } \\
\text { - } & \text { Students not stuck on a weak team }\end{array}$ & - $\quad$ Difficult to manage \\
\hline
\end{tabular}

At the end of the course, student enthusiasm was high, and there is evidence that the learning objectives have been achieved. The instructors have noted an improvement in skills in design, communication, teamwork and reflection over the duration of the course. Many student projects exceeded all expectations, and comments from visitors and guests to the Design Showcase were extremely positive. It was also clear that most student teams had risen to the challenge, and had become highly cohesive and tightly knit. Such positive engineering team experiences are rare, especially in first year.

Some students were disillusioned, as they were uncomfortable with the open-endedness of the projects, or they didn't like all the teamwork and report writing. For a much larger majority, however, the experience was a highly motivating introduction to the excitement of team-based engineering design. Once they understood that it was allowed and even encouraged, students showed that they were capable of being very creative and imaginative in their design solutions.

\section{References}

[1] Manufacturing Education Plan: 1999 Critical Competency Gaps, Society of Manufacturing Engineers, Dearborn MI, 1999, accessed at www.sme.org/foundation/report-phase1_update.pdf
[2] Engineers for Business Excellence: Study among Canadian Auto Industry Engineering Managers, The Strategic Council, July 2002

[3] Criteria for Accrediting Engineering Programs, Effective for Evaluation of Programs During the 20032004 Accreditation Cycle, Accreditation Board for Engineering and Technology (ABET), Baltimore, MD, 2002.

[4] Accreditation Criteria and Procedures, Canadian Engineering Accreditation Board, Canadian Council of Professional Engineers, 2002.

[5] Canadian Design Engineering Network, www.cden.ca, accessed May 13, 2005.

[6] Chairs in Design Engineering (CDE), Natural Sciences and Engineering Research Council of Canada, www.nserc.ca, accessed May 13, 2005.

[7] Thompson, B.E.; J. A. Foster, A. G. Straatman, "Studio Pedagogy for large first-year design courses", Proceedings of the CSME 2004 Forum, July 1-4, 2004, London, Ontario, pp. 281-286.

[8] Thompson, B.E., Foster, J. A., “An Attribute Grading System for Design Projects", Proceedings of the CSME 2004 Forum, July 1-4, 2004, London, Ontario, pp.381-386. 